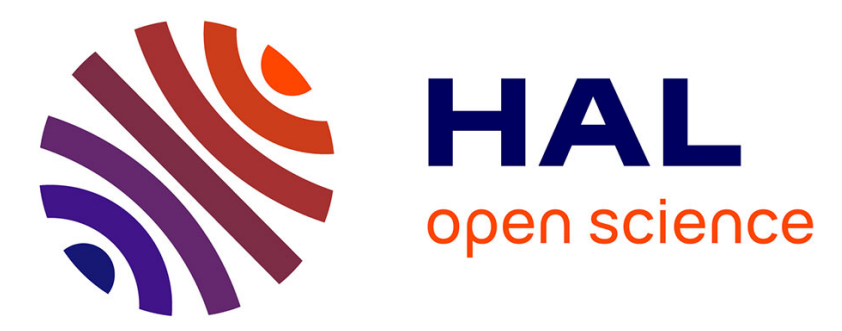

\title{
Environmental Drivers of Microbial Functioning in Mediterranean Forest Soils
}

\author{
Caroline Brunel, Anne Marie Farnet da Silva, Raphaël Gros
}

\section{To cite this version:}

Caroline Brunel, Anne Marie Farnet da Silva, Raphaël Gros. Environmental Drivers of Microbial Functioning in Mediterranean Forest Soils. Microbial ecology, 2020, 80, pp.669-681. 10.1007/s00248020-01518-5 . hal-02649554

\section{HAL Id: hal-02649554 https://hal-amu.archives-ouvertes.fr/hal-02649554}

Submitted on 8 Oct 2020

HAL is a multi-disciplinary open access archive for the deposit and dissemination of scientific research documents, whether they are published or not. The documents may come from teaching and research institutions in France or abroad, or from public or private research centers.
L'archive ouverte pluridisciplinaire HAL, est destinée au dépôt et à la diffusion de documents scientifiques de niveau recherche, publiés ou non, émanant des établissements d'enseignement et de recherche français ou étrangers, des laboratoires publics ou privés. 
1 Research Paper

\section{Title}

3 Environmental drivers of microbial functioning in Mediterranean forest soils

\section{Authors}

5 Caroline Brunel ${ }^{1,2}$, Anne-Marie Farnet Da Silva ${ }^{1}$ and Raphael Gros ${ }^{1}$

$6{ }^{1}$ Mediterranean Institute of marine and continental Biodiversity and Ecology, IMBE, Aix

7 Marseille Université, UMR CNRS 7263, IRD, Avignon Université, Campus l'Etoile, Av.

8 Escadrille Normandie Niemen, 13397, Marseille, Cedex 20, France

92 IRD, IPME; 911 avenue Agropolis, BP 64501, 34394, Montpellier, France

10 Corresponding Author: Caroline Brunel (caroline.brunel@ird.fr, tel: +33 658483 326)

\section{ORCID IDs:}

12 Caroline BRUNEL : 0000-0002-0705-5165

13 Anne-Marie FARNET DA SILVA : 0000-0001-6603-1174

14 Raphael GROS : 0000-0001-6296-0558 


\section{Abstract}

16 Mediterranean forests own distinct characteristics resulting from climate, soil, and vegetation that

17 affect soil microbial communities' assembly and their associated functions. We initiated a multi-

18 scalar analysis of environmental drivers of soil functioning to (1) identify pertinent factorial scales

19 and (2) determine the relative importance of soil, vegetation, and geoclimate relative influences in

20 shaping soil microbial functions across the French Mediterranean forests. Soil samples $(0-15 \mathrm{~cm})$

21 were collected from 60 forest sites and soil physico-chemical and microbiological properties were

22 assessed across different factorial scales i.e., bioclimates, slope exposures, and forest stands.

23 Patterns in microbial catabolic potential (i.e., extracellular enzymes and microbial respiration) and

24 carbon (C) source utilisation (i.e., catabolic-level physiological profiling) were partitioned

25 between vegetation cover, soil characteristics and geoclimate components. Our results reveal that

26 the catabolic potential of soil microbes was strongly influenced by the forest stands, and mainly

27 relied on ammonium and nitrate contents. In contrast, variation in C-source utilisation was mainly

28 explained by vegetation cover. Soil metabolic capacities of microorganisms and resulting C

29 dynamics were largely constrained by climate parameters, which suggests potentially important

30 consequences for soil C storage. Our study revealed diverse structuration patterns between the

31 catabolic potential and the carbon-source utilisation of soil microbial communities, and gives

32 insights into the underlying mechanisms of soil microbial functioning in Mediterranean forests.

\section{Key words}

34 Ecological filters; Mediterranean forest stands; Microbial metabolism; Scale-dependent

35 structuration; Soil microbial communities; Soil physico-chemical properties 


\section{Introduction}

38 Studies of the microbial processes involved in the decomposition of soil organic carbon (C) have

39 considerably increased in recent years owing to the major role soil $\mathrm{C}$ storage plays in the context

40 of climate change [1]. In the $\mathrm{C}$ sink that forest soils represent [2], soil organic $\mathrm{C}$ stocks result

41 largely from the balance between (i) inputs of $\mathrm{C}$ determined by the vegetation cover, (ii) processes

42 of soil C humification by microbial communities and stabilization and (iii) outputs via soil erosion,

$43 \mathrm{CO}_{2}$ production from roots and microorganisms [3]. Thus, $\mathrm{C}$ dynamics in soils depend on complex

44 interactions between climate conditions (e.g. long term mean annual precipitation and temperature)

45 that shape forest structure and tree productivity, soil physico-chemical properties (such as calcium

46 carbonate content and $\mathrm{pH}$ ) influenced by the geological substratum and their combined effect on

47 soil microbial communities and their metabolism [4].

48 Microbes are the primary decomposers of plant material due to their unique ability to produce

49 enzymes to break down both simple molecules such as cellulose and more complex plant derived

50 compounds such as lignin [5]. They mobilize and transform a broad range of soil C substrates,

51 assimilating $\mathrm{C}$ in their biomass, emitting $\mathrm{CO}_{2}$ or stabilizing $\mathrm{C}$ in soil [6]. There is a lot of debate

52 on the potential drivers controlling soil microbiome assembly and the mechanisms maintaining

53 community structure and composition, and we argue that these rules may be better understood if

54 put in perspective (adapted to the needs and contexts). Soil $\mathrm{pH}$, the chemical composition of

55 organic matter $(\mathrm{OM})$, and climate conditions have been pointed out as key driver of soil

56 functioning at local to continental scales [7-11]. In a recent study from different geographical and

57 climatic zones across Europe, variations in bacterial community diversity and structure were

58 mainly driven by parameters corresponding to similar edaphic and climatic properties [12]. 
59 Although these findings provide essential information on soil communities structuration at large

60 scale, the results cannot be transferred to more specific contexts.

61 In the Mediterranean context particularly, where forests are subjected to specific constrains such

62 as drought stress, heat waves, low nutrient availability and recalcitrant organic compounds [13]

63 we still lack a clear understanding of factors controlling microbial $\mathrm{C}$ metabolism and driving soil

$64 \mathrm{C}$ dynamics. Experimental determination of drivers has helped to develop which drivers may be

65 of importance on Mediterranean soils (i.e., soil OM quality and water availability [14, 15]), but a

66 more accurate determination of drivers from measurements done in situ will give greater insight

67 to the mechanisms maintaining microbial communities' structures and functions in these soils.

68 Determining pertinent spatial scales to observe variation in the functioning of such specific soils

69 is now required to clarify how this ecosystem compartment is driven and to assess microbial

70 functioning and $\mathrm{C}$ cycling vulnerability to environmental changes.

71 Here we report on a study designed to (1) determine pertinent factorial scales for unraveling 72 microbial functional patterns and (2) estimate the relative importance of environmental 73 components (vegetation, geoclimate and soil properties) in shaping of soil microbial functioning

74 and (3) identify specific drivers. To disentangle the patterns and drivers of soil microbial 75 functioning in Mediterranean forest soils, we sampled 60 sites covering an area of about 10.000 $76 \mathrm{~km}^{2}$ in south-eastern France. We hypothesized that soil microbial metabolic capabilities and C 77 substrate affinities varied according to bioclimates at a regional scale, side slope exposure at a 78 landscape scale and forest stand at a local scale (Fig. 1) due to environmental variations specific 79 to these scales.

\section{Methods}




\section{Study sites and sampling design}

The sampling was conducted in April 2013 in South-Eastern France (Provence-Alpes-Côte

83 d'Azur), an area characterized by frequent and intense droughts and heat waves typical of the

84 Mediterranean climate. Mean annual temperature and precipitation respectively reach $11.3^{\circ} \mathrm{C}$ and

$85799 \mathrm{~mm}$ (from WorldClim [16], Appendix 2, Fig. S1). Soils are characterized by carbonatic

86 pedofeatures (i.e., fine calcareous silt clay loam). We conducted our study in sub-humid and humid

87 bioclimates [17] corresponding to meso-Mediterranean and supra-Mediterranean altitudinal

88 arrangement of vegetation respectively covered with Pinus halepensis and Quercus ilex, and Pinus

89 sylvestris and Quercus pubescens. Three forest stands were selected for each of the two

90 bioclimates, and were a mono-specific stand of Pinus and a mono-specific stand of Quercus, and

91 a mixed stand 60/40\% of Pinus/Quercus. All forest stands were about $60 \pm 10$ years-old and were

92 without forest management for 35 years. For each of the six types of forests, five 20mX20m plots

93 were selected on both south- and north-facing slopes. These plots were considered to be true

94 replicates as the distance between them exceeded $2 \mathrm{~km}$. All sites were located at altitudes from 500

95 to $900 \mathrm{~m}$ for meso-Mediterranean and from 900 to $1100 \mathrm{~m}$ for supra-Mediterranean bioclimates.

96 Plots were first randomly localized by crossing information from the French Geological Survey

97 (for pedofeature), the Forest Property Regional Center (for forest stands informations) and the

98 National Institute of Geography (for altitude and exposition). The sixty forest plots were visited

99 for cross-validation and were then integrated to the survey (Fig. 1b).

Within each plot, bulk soil samples were collected after removing the litter layer and

101 digging ten small pits over an approximately $20 \mathrm{~cm} \times 20 \mathrm{~cm}$ area (the depth was ranging between

10210 and $15 \mathrm{~cm}$ and was defined by the A horizon limits). The ten sub-samples where sieved (2 $\mathrm{mm})$,

103 pooled and mixed to form a composite sample and placed into a polyethylene bag. In the lab, one 
104 aliquot of each composite sample was stored at $4^{\circ} \mathrm{C}$ for microbial analyses. A second aliquot was

105 air dried in a warm room (48 hours at 30 degrees) for chemical analyses.

\section{Soil chemical characteristics}

Soil water holding capacity (WHC) was determined by the amount of water held in the soil sample vs. the dry weight of the sample. Soil $\mathrm{C}$ and $\mathrm{N}$ content were measured using a $\mathrm{C} / \mathrm{N}$

109 elementary analyzer (Flash EA 1112 ThermoScientific series, Waltham, Massachusetts, USA).

110 Determination of $\mathrm{CaCO}_{3}$ in $10 \mathrm{~g}$ soils (dry weight equivalent) was based on the release of $\mathrm{CO}_{2}$

111 after addition of $\mathrm{HCl} 4 \mathrm{~N}$ [18]. The percentage of inorganic $\mathrm{C}\left(\mathrm{C}\right.$ in $\left.\mathrm{CaCO}_{3}\right)$ was calculated as

112 follows: $\% \mathrm{C}-\mathrm{CaCO}_{3}=11.991 / 100 \times \mathrm{CaCO}_{3}$. Organic $\mathrm{C}$ was calculated as the difference

113 between total $\mathrm{C}$ and inorganic $\mathrm{C}$ contents. Soil $\mathrm{pH}$ was determined in distilled water $(5 \mathrm{~g}$ dry weight

114 in $12.5 \mathrm{~mL}$ ) after a 45 min equilibration [19]. A subsample of $10 \mathrm{~g}$ (dry weight equivalent) was

115 analyzed after extraction in $100 \mathrm{ml}$ of $1 \mathrm{M} \mathrm{KCl}$ with electrodes to determine inorganic $\mathrm{NH}_{4}{ }^{+}$and

$116 \mathrm{NO}_{3}{ }^{-}$concentration in soils (expressed per gram of dried soil).

Soils C biochemical forms were characterized with solid-state ${ }^{13} \mathrm{C}$-NMR spectroscopy

118 using cross-polarization and magic angle spinning (CP-MAS). Spectra were obtained on a Bruker

119 Avance 400MHz NMR spectrometer (Rheinstetten, Germany) at a ${ }^{13} \mathrm{C}$ resonance frequency of 106

$120 \mathrm{MHz}$ and a Bruker double-bearing probe (further detailed in Appendix 1). The relative distribution

121 of $\mathrm{C}$ groups with different structures was determined by integrating the signal intensities over

122 defined chemical shift windows using Dmfit software [20]. Spectra were divided into four

123 chemical regions (Mathers et al., 2003): alkyl C (0-45 ppm), O-alkyl C (45-112 ppm), aromatic C

124 (112-160 ppm) and carbonyl C (160-185 ppm). To describe OM quality, the following ratios of 
125 humification $\left(\mathrm{HR}_{1}\right.$ and $\left.\mathrm{HR}_{2}\right)$ and aromaticity $(\mathrm{AR})$ were calculated [21]: $\mathrm{HR}_{1}=$ alkyl $\mathrm{C} /$ carboxyl C

$126 ; \mathrm{HR}_{2}=$ alkyl C/O-alkyl C ; $\mathrm{AR}=$ aromatic $\mathrm{C} /(\operatorname{alkyl~C}+\mathrm{O}-$ alkyl $\mathrm{C}+$ aromatic $\mathrm{C})$

\section{Soil microbial functioning}

A full description of the methods used for microbial analyses is provided in the Appendix

129 1. Briefly, the determination of $\mathrm{C}$ source utilisation (i.e., catabolic-level physiological profiling,

130 CLPP) was performed using BIOLOG® Eco plate (BIOLOG Inc., Hayward, CA). Plates with an

131 average well colour development (AWCD) of 0.4 were used in the statistical calculations. Shannon

132 index and the mean growth on carbohydrates, carboxylic and ketonic acids, amines/amides,

133 polymers and amino-acids substrates were then determined. Microbial biomass (MB) was

134 estimated using Substrate-Induced Respiration (SIR). Ten grams (dry weight equivalent) of

135 standardized samples at $60 \%$ of WHC were placed in $117 \mathrm{ml}$ flushed-air glass jars and amended

136 with a powder of talc and glucose $(1000 \mu \mathrm{g} \mathrm{C} \mathrm{g-1} \mathrm{soil).} \mathrm{After} \mathrm{ninety} \mathrm{minutes,} 1 \mathrm{ml}$ of air was

137 sampled with a syringe and injected into a gas chromatograph (Chrompack CHROM 3 - CP 9001,

138 Middelburg, The Netherlands) to determine $\mathrm{CO}_{2}$ production. The gas chromatograph was equipped

139 with a thermal conductivity detector and a packed column (Porapack). The carrier gas helium flow

140 was regulated at $60 \mathrm{ml} \mathrm{h}-1$. The $\mathrm{CO}_{2}$ concentration of flushed air was subtracted from the $\mathrm{CO}_{2}$

141 concentration of each sample and resulting values were adjusted to $22^{\circ} \mathrm{C}$ according to Ideal Gas

142 Laws using $\mathrm{Q} 10=2$. Substrate-induced respiration rates were converted into MB using equations

143 given by [22]. Basal respiration was determined without adding glucose and talc powder and was

144 estimated to calculate the metabolic quotient $\mathrm{qCO}_{2}$ (the ratio of basal respiration to microbial

145 biomass), which is a sensitive ecophysiological indicator of soil stress induced by environmental

146 conditions [23]. The activity of five extracellular enzymes (EEA) involved in soil $\mathrm{C}$ and $\mathrm{N}$ cycles

147 were assessed $(n=3)$ for each soil sample to determine the catabolic potential of microbial 
148 communities. Tyrosinase activity was assessed according to the modified method of Saiya-Cork

149 et al. [24]. Two $\mathrm{ml}$ of $25 \mathrm{mM}$ L-DOPA solution (L-3,4-dihydroxyphenylalanine) in potassium

150 phosphate buffer ( $50 \mathrm{mM}, \mathrm{pH} 6.5)$ were added to $0.4 \mathrm{~g}$ of soil (fresh weight), mixed and incubated

151 for $30 \mathrm{~min}$, in darkness at $25^{\circ} \mathrm{C}$. The mixture was centrifuged for 3 minutes at $12000 \mathrm{~g}$ before

152 absorption was measured at $590 \mathrm{~nm}$. Transesterase activity of lipase was assessed according to the

153 method of Goujard et al. [25]. Two $\mathrm{ml}$ of distilled water and $4 \mathrm{ml}$ of $10 \mathrm{mM}$ p-nitrophényl-

154 caprylate in heptane were added to $1 \mathrm{~g}$ of soil (fresh weight) and incubated for $12 \mathrm{~h}$ at $30^{\circ} \mathrm{C}$. The

155 reaction was stopped and colour revealed by adding $200 \mu \mathrm{L}$ of the mixture to $4 \mathrm{~mL}$ of $0.1 \mathrm{M} \mathrm{NaOH}$,

156 which was immediately centrifuged for $2 \mathrm{~min}$ at $12000 \mathrm{~g}$. The amount of $p$-nitrophenol released

157 was measured at $412 \mathrm{~nm}$. Cellulase activity was assayed using CarboxyMethylCellulose (CMC)

$1581 \%$ in $2 \mathrm{~mL}$ of sodium acetate buffer $(50 \mathrm{mM}, \mathrm{pH} 6)$ added to $0.5 \mathrm{~g}$ of soil (fresh weight) incubated

159 for $4 \mathrm{~h}$ at $50^{\circ} \mathrm{C}$. Glucose was quantified according to the Somogyi-Nelson method [26] and

160 absorption was read at $870 \mathrm{~nm}$ [27]. Protease activity was measured using $5 \mathrm{~g}$ of soil (fresh weight)

161 in $5 \mathrm{~mL}$ of casein at $2 \%$ in Tris $\mathrm{HCl}$ buffer $(50 \mathrm{mM}, \mathrm{pH} 8.1)$. The mixture was incubated for 3 hours

162 at $50^{\circ} \mathrm{C}$ and then the reaction was stopped with $5 \mathrm{~mL}$ of Trichloroacetic acid solution (at $15 \%$ ) and

163 the mixture centrifuged (2min, $12000 \mathrm{~g}$ ). Aromatic amino acids were detected using Folin reagent

$164(33 \%)$ at $700 \mathrm{~nm}$. Tyrosine was used as standard. Urease activity was assessed using $0.5 \mathrm{~g}$ of soil

165 (fresh weight) in $2 \mathrm{~mL}$ of urea solution $(80 \mathrm{mM})$ in a sodium acetate buffer $(50 \mathrm{mM}, \mathrm{pH} 6)$. The

166 mixture was incubated for $2 \mathrm{~h}$ at $37^{\circ} \mathrm{C}$ and then centrifuged (2min, $12000 \mathrm{~g}$ ). Ammonium was

167 revealed in microplates using an adapted Mulvaney method (1996) [28]: to 30 $\mu \mathrm{L}$ of the supernatant

168 were added $15 \mu \mathrm{L}$ of EDTA solution, $60 \mu \mathrm{L}$ of Na-salicylate solution and $30 \mu \mathrm{L}$ of hypochlorite

169 solution. After stabilization (45 min), mixture absorption was measured at $667 \mathrm{~nm}$. Enzyme

170 activities were expressed as $\mu$ moles of reaction products released per minute (U) per gram of dry 
171 soil (U.g $\left.{ }^{-1} \mathrm{DS}\right)$. Another $10 \mathrm{~g}$ of soil was incubated for 30 days at $25{ }^{\circ} \mathrm{C}$ and maintained at initial

172 moisture and the selective electrodes (Fisher BioBlock Scientific, Hampton, United-States) were

173 used to determine net ammonification and nitrification rates. Ammonification and nitrification

174 rates are here defined as the difference in concentrations of ammonium and nitrate respectively

175 before and after incubation.

\section{Geoclimate and vegetation variables}

177 Mediterranean forests grow on a wide variety of sites defined by different geoclimatic

178 properties that include climate (e.g., precipitation and temperatures) and physiographic

179 characteristics (e.g., slope, distance to the sea, and elevation), here referred as geoclimate. Climatic

180 data were collected from the WorldClim BioClim dataset $(0.93 \mathrm{~km}$ x $0.93 \mathrm{~km})$. The 19 collected

181 variables (listed in supplementary Methods, Appendix 1, Table S1) represent temperature and

182 precipitation annual trends, seasonality, and extreme or limiting environmental factors and results

183 from interpolations of observed data representative of 1950-2000 [16]. Geographic data (Altitude,

184 Exposure, Slope, Distance to the sea, Latitude and Longitude) were obtained from the National

185 Institute of Geography BD ALTI® database $(1 \mathrm{mx} 1 \mathrm{~m})$. Values were extracted from each site

186 locations using QGIS software (QGIS Development Team, 2.8 ‘Wien’ 2015).

Vegetation cover surveys were based on species identification and overlapped among the different layers that were further analysed using an abundance community matrix (Braun-Blanquet

189 approach [29]. The species composition was determined at each site for tree, shrub and herb

190 layers. Vegetation measurements included the plant species richness, the angiosperm and

191 gymnosperm abundances and their relative abundance, the vegetation evenness, the Shannon

192 diversity indexes of the whole community, and of the herb, shrub and non-tree layers. 


\section{Statistical analyses}

The different variables and matrix considered were summarized in Table S1 (Appendix 1).

195 Two sets of microbiological data were obtained, and were a matrix of the catabolic potential based

196 on the EEA and SIR analyses and a matrix of C source utilisation based on CLPP. Three

197 environmental datasets (i.e., soil, geoclimate [hereafter geoclimate variables] and vegetation were

198 constituted respectively from 12 soil variables, 25 geoclimate variables, and from the vegetation

199 cover. Dissimilarity matrix were calculated based on Euclidian distances for geoclimate, soil,

200 CLPP and EEA datasets and Manhattan distance for the vegetation cover.

Permutational analysis of variance (PERMANOVA), implemented in the 'adonis' function

202 ('vegan' package [30]), were used to test for significant effects of the factorial scales and their 203 interaction on the environmental components (distance matrixes).

The effects of factorial scales and their interaction on each microbial and soil variable were also addressed using analysis of variance (ANOVA) on linear models. Shapiro and Levene tests were respectively used to assess the normality and equality of variances. Variables that did not fit

207 linear model requirements were transformed using the 'bestNormalize' function ('bestNormalize' package, Peterson, 2018). Used transformations are listed in the Table S1 (Appendix 1). on microbial functioning, their variations were examined as follows. First, non-metric

211 multidimensional scaling (NMDS), which were best designed to represent the ordering

212 relationships among objects in a small and specified number of axes [31], were used for variable

213 reduction [33] of each distance matrixes and the 5 first axis were subsequently used. Then,

214 variations in microbial functioning were partitioned into the pure effects of geo-climatic, soil and 
215 vegetation components (i.e., variation of the model explained independently by each factor) and

216 into their interactions (i.e., variation of the model explained simultaneously by two or three factors)

217 using constrained and un-constrained distance-based redundancy analysis (db-RDA, function

218 'varpart', vegan package [30]). The significance of the testable fractions was determined by

219 ANOVA of the partial db-RDA test using 999 permutations and results were represented by Venn 220 diagrams.

221 Unconstrained RDA were then performed on models that considered a subset of the 222 environmental variables. We first reduced the number of explanatory variables based on a variance 223 inflation factor (VIF) analysis to account for multicollinearity among covariates [34]. Variance 224 inflation factor values were calculated for a full model then for a reduced model obtained by 225 sequentially deleting each variable for which the VIF was the highest until all remaining VIFs 226 were below 2 [35]. Significance of covariates was tested by ANOVA using 999 permutations. by determining the Spearman correlation coefficient (rho).

All statistical analyses were performed using R version 3.5.0. To account for multiple comparisons Benjamini and Hochberg false discovery rate corrections were applied when

231 required [36].

\section{Results}

233 Relevance of bioclimate, slope exposure and forest stand in shaping soil functioning patterns

234 First, PERMANOVA were performed to test the effects of the different factorial scales and their 235 interaction on both the microbiological and environmental components (Fig. 2 and Table S1 in 
Appendix 2). Bioclimates explained a low but significant part of variation in both $\mathrm{C}$ source

237 utilisation $\left(\mathrm{F}=2.28, \mathrm{r}^{2}=0.04, \mathrm{p}=0.006\right)$ and in catabolic potential $\left(\mathrm{F}=4.15, \mathrm{r}^{2}=0.06, \mathrm{p}=0.005\right)$.

238 PERMANOVA also revealed modification in enzymatic rates induced by forest stands $(\mathrm{F}=2.503$,

$\left.239 \mathrm{r}^{2}=0.08, \mathrm{p}=0.011\right)$. As expected, variation in geoclimate and vegetation cover were well described

240 both across bioclimates $\left(\mathrm{F}=124.88, \mathrm{r}^{2}=0.66, \mathrm{p}=0.001\right.$ and $\mathrm{F}=42.831, \mathrm{r}^{2}=0.37, \mathrm{p}=0.001$,

241 respectively) and the interaction between bioclimate and forest stands $\left(\mathrm{F}=3.75, \mathrm{r}^{2}=0.19, \mathrm{p}=0.020\right.$

242 and $\mathrm{F}=4.11, \mathrm{r}^{2}=0.07, \mathrm{p}=0.001$, respectively). Both bioclimate and forest stand defined pertinent

243 scales that could be used to disentangle variations in soil microbial functioning. Bioclimate was

244 the main factor driving microbial functioning. In contrast, variation due to slope exposure was

245 imperceptible on soil, vegetation cover or microbial patterns. It is worth mentioning here that we

246 observed differences in both mean annual temperatures and annual precipitation between north-

247 and south-exposed sites in both meso- and supra-Mediterranean contexts (Appendix 2, Fig. S1),

248 but did not capture the expected lower temperatures on north-facing slopes in the supra-

249 Mediterranean context. Additionally, PERMANOVA revealed that soil properties were not

250 structured through any of the considered scales, suggesting that soil physico-chemical

251 characteristics were likely to be driven at larger or smaller scales.

252 Bioclimates had a substantial effect on both soil physico-chemical and microbial characteristics

253 (Fig. 3 and Table S2 in Appendix 2). Total N ( $\mathrm{F}=21.893$, $\left.\mathrm{p}_{\text {adj }}<0.001\right)$ and organic $\mathrm{C}$ content $254\left(\mathrm{~F}=27.761, \mathrm{p}_{\mathrm{adj}}<0.001\right.$, Fig. $\left.3 \mathrm{~h}\right)$ indicated a greater quantity of $\mathrm{OM}$ in soils from meso- than from 255 supra-Mediterranean forests together with a higher water holding capacity of the soils ( $\mathrm{F}=11.513$, $256 p_{\text {adj }}=0.008$, Fig. $3 \mathrm{~g}$ ). On the other hand, certain characteristics of soil linked with the inorganic

257 fraction, such as calcium carbonate and $\mathrm{pH}$, did not vary between bioclimates. No differences in 258 OM aromaticity (AR) were observed between the two bioclimates, while a higher amount of 
organic acids with long alkyl-chains $\left(\mathrm{HR}_{1}, \mathrm{~F}=8.725\right.$, $\mathrm{p}_{\mathrm{adj}}=0.0019$, Fig. $\left.3 \mathrm{i}\right)$ was found in supra-

260 Mediterranean forest soils. This suggested a higher humification rate associated with production

261 of organic acids with short-alkyl chains $\left(\mathrm{F}=16.104\right.$, $\mathrm{p}_{\mathrm{adj}}=0.001$, Fig. $\left.3 \mathrm{j}\right)$ in meso-Mediterranean

262 soils.

263 None of the enzyme potential or $\mathrm{C}$ source preferences was differently expressed between the two

264 bioclimates although the H' index calculated from CLPP indicated slightly but not significantly

265 higher functional diversity in meso-Mediterranean soils $\left(\mathrm{F}=5.160, \mathrm{p}=0.028\right.$, $\left.\mathrm{p}_{\text {adj }}=\mathrm{ns}\right)$. Relating

266 microbial-C to organic-C underlined a higher biomass content per unit of OM in supra-

267 Mediterranean soils $\left(\mathrm{F}=23.517\right.$, padj $<0.001$, Fig. 31). The catabolic quotient $q \mathrm{CO}_{2}$ was also higher

268 in the meso-Mediterranean context $\left(\mathrm{F}=20.499, \mathrm{p}_{\mathrm{adj}}<0.001\right.$, Fig. $\left.3 \mathrm{k}\right)$.

269 Both slope exposure and forest stand had substantial influences on microbial parameters and soil

270 characteristics. Cellulase activity was higher on south-facing slopes $\left(\mathrm{F}=14.132\right.$, $\mathrm{p}_{\mathrm{adj}}=0.011$, Fig.

271 3f), where we observed slightly higher carboxyl C and WHC (respectively, F=7.002, $p=0.011$,

$272 \mathrm{p}_{\mathrm{adj}}=\mathrm{ns}$ and $\left.\mathrm{F}=5.061, \mathrm{p}=0.029, \mathrm{p}_{\mathrm{adj}}=\mathrm{ns}\right)$. The influence of forest stand was expressed on

273 measurements of $\mathrm{OM}$ recalcitrance, i.e $\mathrm{N}$ content and $\mathrm{C} / \mathrm{N}$ ratio, aromatic $\mathrm{C}$ and $\mathrm{AR}$ ratio, and

274 tyrosinase activity. Total $\mathrm{N}$ content was higher in soils of oak than pinewoods and mixed stands

$275\left(\mathrm{~F}=20.872\right.$, $\mathrm{p}_{\mathrm{adj}}=0.006$, Fig. 3a), which resulted in the opposite $\mathrm{C} / \mathrm{N}$ trend $\left(\mathrm{F}=20.368, \mathrm{p}_{\mathrm{adj}}<0.001\right.$,

276 Fig. 3c). Aromatic content and Ar ratio ( $\mathrm{F}=8.061$, $\mathrm{p}_{\mathrm{adj}}=0.006$, Fig. $\left.3 \mathrm{~d}\right)$ were higher in pinewoods

277 (F=9.557, $\left.\mathrm{p}_{\text {adj }}=0.004\right)$. Pinus forests soils, characterized by lower $\mathrm{N}$ and higher $\mathrm{pH}(\mathrm{F}=6.333$,

$278 p_{\text {adj }}=0.020$, Fig. 3e), were observed together with a weaker tyrosinase activity $(\mathrm{F}=8.141$, $279 p_{\text {adj }}=0.006$, Fig. 3b). 
281 Because microbial patterns varied between the two bioclimates, variance partitioning analyses

282 were carried out at both regional and sub-regional scales to determine the effects of geoclimate,

283 soil and vegetation on both C source utilisation and catabolic potential patterns (Fig. 4 and Table

284 S3, Appendix 2).

285 Overall explanation by environmental components reached $c a .30 \%$ and $45 \%$ of the $\mathrm{C}$ source 286 utilisation (Fig. 4a) and of catabolic potential respectively (Fig. 4d) at the regional scale, and

287 increased to $c a .50 \%$ (Fig.4b, 4c) and 65\% (Fig. 4e, 4f) at landscape and local scales respectively.

288 Carbon source utilisation patterns were mainly and significantly influenced by vegetation cover

$289\left(\mathrm{~F}=1.352, \mathrm{r}^{2}=0.11, \mathrm{p}=0.030\right.$, Fig. $\left.4 \mathrm{a}\right)$ at the regional scale, but no significant influences of the three

290 components were observed at sub-regional meso- and supra-Mediterranean scales (Fig. 4b, 4c).

291 Soil physico-chemical prints explained a large part of variation in microbial catabolic potential at

292 both regional (shared effect: $\mathrm{F}=5.111, \mathrm{r}^{2}=0.32, \mathrm{p}=0.001$; pure effect: $\mathrm{F}=3.929, \mathrm{r}^{2}=0.243$, $\mathrm{p}=0.001$,

293 Fig. 4d) and sub-regional scales. In meso-Mediterranean forest, variation in catabolic potential was

294 due to the shared effect of soil properties $\left(\mathrm{F}=3.288, \mathrm{r}^{2}=0.406, \mathrm{p}=0.001\right.$, Fig. $\left.4 \mathrm{e}\right)$ encompassing $16 \%$

295 of vegetation-soil common explanation. In supra-Mediterranean forests, both soil (shared effect:

$296 \mathrm{~F}=2.747, \mathrm{r}^{2}=0.364, \mathrm{p}=0.003$; pure effect: $\mathrm{F}=2.376, \mathrm{r}^{2}=0.0255$, $\mathrm{p}=0.004$, Fig. 4f) and vegetation

297 (pure effect: $\mathrm{F}=1.902, \mathrm{r}^{2}=0.204$, $\mathrm{p}=0.029$, Fig. $4 \mathrm{f}$ ) explained variation in catabolic potential.

\section{Driving forces of soil microbial functioning}

299 To disentangle effects of specific drivers amongst the edaphic, geoclimate and vegetation

300 components, we tested the influence of the main environmental covariates on soil microbiological

301 patterns. Collinear factors were first removed sequentially based on their VIF scores. Remaining

302 covariates included site exposition, slope, longitude, mean temperature of the wettest quarter, 
$303 \mathrm{CaCO}_{3}$, total $\mathrm{N}$, carboxyl $\mathrm{C}$, O-alkyl C, nitrate, ammonium, bulk density, and vegetation richness

304 (Table S4, Appendix 2). Only edaphic parameters stand out as driving forces of microbial

305 functioning patterns. Carbon source utilisation was related to total $\mathrm{N}$ content at regional scale

$306(\mathrm{~F}=1.825, \mathrm{p}=0.019)$, and to soil bulk density in supra-Mediterranean forests $(\mathrm{F}=1.698, \mathrm{p}=0.035)$.

307 Catabolic potential was structured by $\mathrm{CaCO}_{3}(\mathrm{~F}=9.49, \mathrm{p}=0.001)$, total $\mathrm{N}(\mathrm{F}=7.389, \mathrm{p}=0.001)$,

308 nitrate $(\mathrm{F}=5.320, \mathrm{p}=0.002)$ and ammonium $(\mathrm{F}=3.157, \mathrm{p}=0.009)$ content at regional scale, and by

$309 \mathrm{CaCO}_{3}$ content $(\mathrm{F}=5.780, \mathrm{p}=0.001)$ in meso-Mediterranean context.

310 To further describe underlying mechanisms of microbial functioning, we examined relationships

311 linking microbial assemblages to environmental parameters (Fig. 5 and supplementary Fig. 2 in

312 Appendix 2). Carbon source preferences and associated functional diversity index were unrelated

313 to environmental variables. Five edaphic parameters were favoring soil microbial properties: the

$314 \mathrm{BR}, q \mathrm{CO}_{2}$, urease, tyrosinase, and cellulase increased with soil WHC; BR, MB and urease activity

315 increased with the soil alkyl $\mathrm{C}$ fraction; $\mathrm{BR}$ and $q \mathrm{CO}_{2}$ increased with soil organic $\mathrm{C}$ content, $\mathrm{MB}$

316 and $\mathrm{MB}$ per unit of organic $\mathrm{C}$ increased with $\mathrm{HR} 1$. Soil $\mathrm{pH}$ and $\mathrm{CaCO}_{3}$ both negatively affected

$317 \mathrm{BR}, \mathrm{MB}$ and tyrosinase activity. The metabolic quotient $\left(q \mathrm{CO}_{2}\right)$ was particularly sensitive to

318 several climate parameters as it was upregulated by temperature indexes (MTWaQ, min TCM,

319 MTDQ, MTCQ, annual MT, max MTWaM) and downregulated by precipitation indexes (annual

320 P, PWaQ, PDQ and PDM). Interestingly, tyrosinase activity was restrained by gymnosperm total

321 and relative abundances together with plant species richness. Although vegetation has been

322 previously shown to influence overall soil microbial patterns, vegetation diversity indexes were

323 not directly related to any specific microbial markers, suggesting that forest community

324 composition rather that forest community structure plays an important role in microbial

325 functioning. 


\section{Discussion}

\section{Multiple scaling of soil microbial functioning}

328

330

331

332

333

334

335

336

338

339

341

342

344

345

346

347

348

Comparison between $\mathrm{C}$ utilisation and microbial catabolic potential patterns highlighted different structuration scales (i.e., a strong influence of bioclimates on $\mathrm{C}$ source utilization vs. a finer effect of forest stands on catabolic potentials), and testified to scale-dependent variations in microbial functioning. While limitations in the BIOLOG methodology for the characterization of whole communities are well known, CLPP remain a useful tool to detect culturable copiotrophic bacteria living in forest soil [37]. Fungi have broader enzymatic capabilities [38] and potentially greater C use efficiency [39] than bacteria. Shift in the respective functional capabilities of fungi and bacteria could partly explain the observed patterns (Fig. 2d and 2e), with substantial implications relevant to $\mathrm{C}$ and $\mathrm{N}$ cycling as these taxa own distinct $\mathrm{C}$ use efficiencies [40].

Variation in C source utilisation was detected between the two bioclimates considered, and was mainly explained by vegetation cover (Fig. 4). However, $\mathrm{C}$ use patterns did not differ between forest stands and no substrate preference has been related with descriptor of vegetation (Fig. 5). This suggested that some plant species associated with bioclimates influenced C-substrate affinity over the dominant tree species considered here. Previous studies in grasslands showed modification in soil microbial communities in response to plant community composition [41, 42] but fewer considered treed ecosystems [43, 44], and to our knowledge, only one considered CLPP profiles. In this study [45], both tree diversity and identity affected CLPP. Tree species and even tree genotypes have been previously shown to influence litter chemistry and to control $\mathrm{C}$ and nutrient dynamics [46, 47]. Although not further tested here, it is likely that the observed modifications in CLPP reveal a shift in community composition of copiotrophic bacteria [37], that preferentially consume the labile pool of organic C (e.g., freshly fallen litter) [48]. The main driver 
349 of $\mathrm{C}$ use patterns was the total $\mathrm{N}$ content, which has previously been revealed as a driver of

350 microbial functional and taxonomic diversity. For instance, Fierer et al. [10] observed shifts in C

351 use utilisation across $\mathrm{N}$ gradients together with bacterial phylogenetic and metagenomic responses.

352 Moreover, in our study, functional diversity decreased with soil $\mathrm{pH}$, which has often been pointed

353 out as an important driver of bacterial diversity [49] and of functional diversity approached via

354 CLPP [50].

Unlike C source utilisation, catabolic potential patterns were shaped by forest stands beyond the influence of bioclimates, and more strongly relied on N-related markers (i.e., nitrate, ammonium and total $\mathrm{N}$ content). This is likely because decomposer $\mathrm{N}$-requirements are not completely fulfilled by $\mathrm{N}$ plant litter concentration [51]. Nitrogen has to be immobilized by decomposers from their resources until the elements reach a critical threshold that allows $\mathrm{N}$ conversion into microbial biomass or production of EEA [52]. Nitrogen content significantly changed across the six forest stands considered in our study with particularly exacerbated

362 differences between oak and pine forests. Such differences in OM quality between these

363 Mediterranean tree species have been previously shown together with significant consequences in

364 the resulting soil organic $\mathrm{C}$ stocks [53]. These results together indicate that the functional 365 composition of microbial communities (estimated through the $\mathrm{C}$ uses) is shaped at larger scales 366 than their actual catabolic potential, which relies on marker of OM quality defined at the forest 367 stand scale.

\section{Differential microbial functioning across bioclimates}

369 It is a central principle of biogeography that climate exerts a dominant control over the natural

370 distribution of species [54]. In our study, we revealed that the vegetation stage was not a suitable 
371 predictor of soil chemical properties. According to Pons and Quézel (1998) [55], the meso-

372 Mediterranean bioclimate corresponds to a warm bioclimate with drought waves, while supra-

373 Mediterranean winters are harsher and summer more temperate. In the Mediterranean context,

374 vegetation has acquired morphological traits to face the deficit of water, e.g. slow growth, thick

375 cuticle, allelopathic compounds and low nutrient content [56]. These particular climate conditions,

376 exacerbated in meso-Mediterranean forests, select sclerophyllous vegetal species (such as Quercus

377 ilex, Quercus coccifera etc.) that we expected to detect in soil physico-chemical prints. We did not

378 detect such general pattern. However, a higher carboxyl C contents in meso-Mediterranean soils

379 could relate to a larger sclerophyllous plant community in meso-Mediterranean forests (as

380 carboxyl C reflects the cutin polymer of leaves cuticle [57]).

Meso-Mediterranean soils were characterized by higher organic C and WHC. Water

382 holding capacity in soil relies on its OM content [58]. Differences in C content can be driven by

383 higher C inputs (i.e., primary production) and/or by lower microbial mineralization rates. Calcium

384 carbonate content had a strong influence in shaping microbial catabolic potential, even more

385 pronounced in meso-Mediterranean soils. Exchangeable calcium positively correlates with SOC

386 concentration and its resistance to microbial degradation [59]. This is in line with our results that

387 point out higher organic $\mathrm{C}$ in meso-Mediterranean soils where the $\mathrm{CaCO}_{3}$ content had higher

388 influence on the microbial catabolic potential. As water molecules prevent the direct approach or

389 sorption of an organic substance to a mineral's surface [59], lower precipitation in meso-

390 Mediterranean forests might have increase an inhibitor effect of $\mathrm{CaCO}_{3}$ on microbial catabolic

391 potential.

392

Slightly higher functional microbial diversity under recalcitrant vegetation and more arid

393 conditions from meso-Mediterranean could suggest a shift of functional communities [60] since 
394 harsher conditions tend to select resistant and specialist populations corresponding to an

395 oligotrophic lifestyle [61]. Tardy et al. [62] showed that a higher microbial diversity improved the

396 functional stability of microbial communities after heat stresses, which are common in the meso-

397 Mediterranean bioclimate. We also found respectively a small and a significant increase in

398 microbial basal respiration and in $q \mathrm{CO}_{2}$ of meso-Mediterranean forest soils that suggests a better

399 potential for mineralization in meso-Mediterranean when water is available (60 \% WHC). Thus,

400 in meso-Mediterranean forest soils, when hydric conditions are suitable, the mineralization

401 potential is likely to be high and to lead to $\mathrm{CO}_{2}$ production (for instance in spring and fall), while

402 during summer drought, $\mathrm{OM}$ decomposition is probably drastically inhibited. This suggests that

403 the observed higher $\mathrm{C}$ contents in the meso-Mediterranean context then result from climate

404 constraints.

405 Detection of variations in microbial functioning at smaller scales

406 We found that soil chemical and microbial characteristics (total $\mathrm{N}$, aromatic $\mathrm{C}$ and

407 tyrosinase activity) related to OM recalcitrance varied among forest stands (Fig. 3 a-e). In a

408 previous study, Brunel et al. [53] investigated the effect of relative oak/pine tree composition using

409 the same tree species and bioclimates and determined that relative aromatic content increased

410 linearly with pine abundance. Recalcitrant OM, mainly aromatic compounds, limits microbial

411 growth by toxic effects on microbial cells (for instance on membranes), limiting bioavailability of

412 nutrients, and can also bind to microbial enzymes and inhibit their activities [63, 64]. As soil $\mathrm{N}$ is

413 tightly bound to recalcitrant humic acids, a limited availability and/or quantity of $\mathrm{N}$ under

414 pinewood is likely to enhance aromatic $\mathrm{C}$ accumulation in pine stands [65]. 
416 influence on radiation, temperature and moisture [66], and indirectly by affecting vegetation cover

417 and structures [67]. Variations in geoclimate were not perceptible between south- and north facing

418 slopes. This can point out two mutually non-exclusive scenarios: (i) that the used climate data are

419 unsuitable to unravel differences at the slope scale (pixel of $0.86 \mathrm{~km}^{2}$ for the BioClim modeled

420 variables [16]), and/or (ii) that microclimatic variations between sites were consistently larger than

421 the variations caused by differences induced by slope exposure. We detected higher cellulase

422 activities in soils of south-exposed forests, and slight modifications in carboxyl C content. In

423 contrast with our results, differences in vegetation cover between north- and south-facing slopes

424 have been previously reported in Mediterranean areas; overall vegetation cover and species

425 richness were shown to be reduced on north-facing slopes and a greater number of evergreen

426 species have been observed on south slopes [68, 69]. In their study on forest soils, Måren et al [70]

427 showed that, in arid environments, slope aspect is less important in driving soil properties than in

428 moister environments where more microclimatic contrasts are observed.

Environmental drivers and their potential implications in the context of climate change

While Mediterranean forests have the potential to strongly contribute to global C sink [71],

431 their SOC stocks are known to be lower than other forest types. This pattern is commonly

432 explained by factors such as landuse legacy (abandoned pastures) and fire frequency, and also by

433 the low productivity of Mediterranean tree species [72]. Here we also observed that soil microbial

434 functioning is largely explained by climate parameters. We reported above that C stocks in meso-

435 Mediterranean forest soils resulted from climate constraints. Two other observations tend to reveal

436 that soil microbial functioning in Mediterranean forest soils is controlled by climate variation.

437 First, $\mathrm{qCO}_{2}$, which indicates the efficiency by which soil microorganisms use C-resources in soil 
438 [73], was strongly associated to climate variation (up-regulated by 6 indexes of temperature and

439 down-regulated by 5 indexes of precipitation). Then, 5 microbial markers (i.e., basal respiration,

440 metabolic quotient, urease, tyrosinase, cellulase activities and ammonium mineralization rate)

441 were strongly related to the water holding capacity, which reflects the water-balance fluctuations

442 in soils. As in the Mediterranean region, average annual temperatures are well above current global

443 warming trends [74], our results suggest that soil microbial functioning and resulting $\mathrm{C}$ dynamics

444 will be drastically affected in the coming years. Our results support recent findings of Diamond et

445 al. [75] who reveal that climate change can have a direct impact on the relative abundance and

446 metabolic capacities of microorganisms in Mediterranean soil ecosystems, with potentially

447 important impacts for both soil C storage and gas release.

\section{Conclusion}

449 The use of a multi-scalar sampling design allowed us to show the prevailing influence of 450 bioclimates and forest stands in controlling soil functioning over slope exposure and provide 451 insights into the underlying mechanisms. Because climate is responsible for vegetation type, which 452 in turn provides different soil $\mathrm{C}$ substrates that are metabolized under different conditions (e.g., 453 temperature or moisture), the bioclimate effect per se is hard to disentangle. However, by 454 describing variations associated with the bioclimate in soil properties, climate and vegetation 455 cover, this study provides clues on which facet of the bioclimatic context (i.e., geo-climate, soil or 456 vegetation) are the most structuring. We found that vegetation cover better explained variations in 457 C source utilization, whereas edaphic characteristics better explained variations in catabolic 458 potential of microbial communities. These results, therefore, contribute to a better understanding 459 of the environmental drivers of microbial functioning across the French Mediterranean landscape. 460 Further studies focusing on soil metabarcoding and transcriptomic would be required to shed light 
461 on the environmental filters of microbial composition in relation to their expressed metabolism,

462 and on the drivers of bacterial and fungal communities respectively.

\section{Acknowledgments}

464 The project received funding from the French Environment and Energy Management 465 Agency (ADEME) and Region Provence Alpes Côte d'Azur (France). We thank Florence

466 Ruaudel, Fabio Ziarelli, and Sebastien Milanesio for their technical assistance and are grateful to

467 the Forest Property Regional Center (CRPF) for their contribution, especially to Olivier Martineau 468 for his valuable support in determining the selected sites.

469 
471 1. Bradford MA, Wieder WR, Bonan GB, et al (2016) Managing uncertainty in soil carbon

472 feedbacks to climate change. Nat Clim Change 6:751

473 2. Lal R (2005) Forest soils and carbon sequestration. For Soils Res Theory Real Its Role 474 Technol Sel Ed Pap 10th North Am For Soils Conf Held Saulte Ste Marie Ont Can 20-24 July 2003 220:242-258. https://doi.org/10.1016/j.foreco.2005.08.015

3. Tian H, Lu C, Yang J, et al (2015) Global patterns and controls of soil organic carbon

4. Pan Y, Birdsey RA, Fang J, et al (2011) A Large and Persistent Carbon Sink in the World's

5. Romaní AM, Fischer H, Mille-Lindblom C, Tranvik LJ (2006) Interactions of bacteria and fungi on decomposing litter: differential extracellular enzyme activities. Ecology 87:25592569

6. Bardgett RD, Freeman C, Ostle NJ (2008) Microbial contributions to climate change

7. Davidson EA, Janssens IA (2006) Temperature sensitivity of soil carbon decomposition and feedbacks to climate change. Nature 440:165-173

8. Rousk J, Baaath E, Brookes PC, et al (2010) Soil bacterial and fungal communities across a $\mathrm{pH}$ gradient in an arable soil. ISME J 4:1340-1351

9. Rousk J, Brookes PC, Baath E (2009) Contrasting soil pH effects on fungal and bacterial growth suggest functional redundancy in carbon mineralization. Appl Env Microb 75:.

10. Fierer N, Lauber CL, Ramirez KS, et al (2012) Comparative metagenomic, phylogenetic and physiological analyses of soil microbial communities across nitrogen gradients. ISME J 6:1007-1017. https://doi.org/10.1038/ismej.2011.159

11. Bonanomi G, Capodilupo M, Incerti G, Mazzoleni S (2014) Nitrogen transfer in litter mixture enhances decomposition rate, temperature sensitivity, and C quality changes. Plant Soil 381:307-321. https://doi.org/10.1007/s11104-014-2119-4

12. Plassart P, Prévost-Bouré NC, Uroz S, et al (2019) Soil parameters, land use, and geographical distance drive soil bacterial communities along a European transect. Sci Rep 9:1-17. https://doi.org/10.1038/s41598-018-36867-2 communities in a Mediterranean pine forest. New Phytol 220:1211-1221. 
505

506

507

508

509

510

511

512

513

514

515

516

517

518

519

520

521

522

523

524

525

526

527

528

529

530

531

532

533

534

535

536

537

538

539

14. Brunel C, Gros R, Lerch TZ, Da Silva AMF (2020) Changes in soil organic matter and microbial communities after fine and coarse residues inputs from Mediterranean tree species. Appl Soil Ecol 149:103516

15. Boukhdoud N, Silva AMFD, Darwish T, Gros R (2017) Olive mill waste and glyphosatebased herbicide addition to olive grove soils: effects on microbial activities and their responses to drying-rewetting cycles. Soil Use Manag 33:499-510. https://doi.org/10.1111/sum.12367

16. Hijmans RJ, Cameron SE, Parra JL, et al (2005) Very high resolution interpolated climate surfaces for global land areas. Int J Climatol 25:1965-1978. https://doi.org/10.1002/joc. 1276

17. Medail F, Quezel P (2003) Que faut-il entendre par" forêts méditerranéennes"? XXIV:

18. Chaney RC, Slonim SM, Slonim SS (1982) Determination of calcium carbonate content in soils. In: Geotechnical properties, behavior, and performance of calcareous soils. ASTM International, 3-15, https://doi.org/101520/STP28907S

19. Aubert G (1978) Méthodes d'analyses des sols. Centre national de documentation pédagogique, Centre régional de documentation pédagogique de Marseille

20. Massiot D, Fayon F, Capron M, et al (2002) Modelling one-and two-dimensional solid-state NMR spectra. Magn Reson Chem 40:70-76

21. Baldock J, Preston CM (1995) Chemistry of carbon decomposition processes in forests as revealed by solid-state 13C NMR. 89-117, https://doi.org/10.2136/1995.carbonforms.c6

22. Beare MH, Neely CL, Coleman DC, Hargrove WL (1990) A substrate-induced respiration (SIR) method for measurement of fungal and bacterial biomass on plant residues. Soil Biol Biochem 22:585-594. http://dx.doi.org/10.1016/0038-0717(90)90002-H

23. Anderson T-H (2003) Microbial eco-physiological indicators to asses soil quality. Agric Ecosyst Environ 98:285-293. http://dx.doi.org/10.1016/S0167-8809(03)00088-4

24. Saiya-Cork K, Sinsabaugh R, Zak D (2002) The effects of long term nitrogen deposition on extracellular enzyme activity in an Acer saccharum forest soil. Soil Biol Biochem 34:13091315

25. Goujard L, Villeneuve P, Barea B, et al (2009) A spectrophotometric transesterificationbased assay for lipases in organic solvent. Anal Biochem 385:161-167

26. Ladd J, Butler J (1972) Short-term assays of soil proteolytic enzyme activities using proteins and dipeptide derivatives as substrates. Soil Biol Biochem 4:19-30

27. Farnet Da Silva AM, Qasemian L, Guiral D, Ferré E (2010) A modified method based on arsenomolybdate complex to quantify cellulase activities: Application to litters.

Pedobiologia 53:159-160. http://dx.doi.org/10.1016/j.pedobi.2009.09.001 
28. Mulvaney DL, America SSS of, Agronomy AS of (1996) Methods of Soil Analysis Part 3: Chemical Methods. Amer Society of Agronomy, Madison, Wis

29. Braun-Blanquet J (1932) Plant sociology. The study of plant communities. First ed. Plant Sociol Study Plant Communities First Ed

30. Dixon P (2003) VEGAN, a package of R functions for community ecology. J Veg Sci 14:927-930. https://doi.org/10.1111/j.1654-1103.2003.tb02228.x

31. Peterson RA (2018) bestNormalize: Normalizing Transformation Functions, R package version 1.2. 0

32. Borcard D, Gillet F, Legendre P (2018) Unconstrained Ordination. In: Borcard D, Gillet F, Legendre P (eds) Numerical Ecology with R. Springer International Publishing, Cham, pp $151-201$

33. Quinn GP, Keough MJ (2002) Experimental design and data analysis for biologists. Cambridge University Press

34. James G, Witten D, Hastie T, Tibshirani R (2013) An introduction to statistical learning. Springer

35. Zuur AF, Ieno EN, Elphick CS (2010) A protocol for data exploration to avoid common statistical problems. Methods Ecol Evol 1:3-14

36. Benjamini Y, Hochberg Y (1995) Controlling the False Discovery Rate: A Practical and Powerful Approach to Multiple Testing. J R Stat Soc Ser B Methodol 57:289-300

37. Lladó S, Baldrian P (2017) Community-level physiological profiling analyses show potential to identify the copiotrophic bacteria present in soil environments. PLOS ONE 12:e0171638. https://doi.org/10.1371/journal.pone.0171638

38. Waring BG, Averill C, Hawkes CV (2013) Differences in fungal and bacterial physiology alter soil carbon and nitrogen cycling: insights from meta-analysis and theoretical models. Ecol Lett 16:887-894. https://doi.org/10.1111/ele.12125

39. Six J, Frey SD, Thiet RK, Batten KM (2006) Bacterial and Fungal Contributions to Carbon Sequestration in Agroecosystems. Soil Sci Soc Am J 70:555-569. https://doi.org/10.2136/sssaj2004.0347

40. McGuire KL, Treseder KK (2010) Microbial communities and their relevance for ecosystem models: Decomposition as a case study. Soil Biol Biochem 42:529-535. https://doi.org/10.1016/j.soilbio.2009.11.016

41. Bardgett RD, Shine A (1999) Linkages between plant litter diversity, soil microbial biomass and ecosystem function in temperate grasslands. Soil Biol Biochem 31:317-321 
573

574

575

576

577

578

579

580

581

582

583

584

585

586

587

588

589

590

591

592

593

594

595

596

597

598

599

600

601

602

603

604

605

606

607

608

42. Eisenhauer N, Beßler H, Engels C, et al (2010) Plant diversity effects on soil microorganisms support the singular hypothesis. Ecology 91:485-496. https://doi.org/10.1890/08-2338.1

43. Scheibe A, Steffens C, Seven J, et al (2015) Effects of tree identity dominate over tree diversity on the soil microbial community structure. Soil Biol Biochem 81:219-227. https://doi.org/10.1016/j.soilbio.2014.11.020

44. Thoms C, Gattinger A, Jacob M, et al (2010) Direct and indirect effects of tree diversity drive soil microbial diversity in temperate deciduous forest. Soil Biol Biochem 42:15581565. https://doi.org/10.1016/j.soilbio.2010.05.030

45. Khlifa R, Paquette A, Messier C, et al (2017) Do temperate tree species diversity and identity influence soil microbial community function and composition? Ecol Evol 7:79657974. https://doi.org/10.1002/ece3.3313

46. Chavez-Vergara B, Merino A, Vázquez-Marrufo G, García-Oliva F (2014) Organic matter dynamics and microbial activity during decomposition of forest floor under two native neotropical oak species in a temperate deciduous forest in Mexico. Geoderma 235236:133-145. https://doi.org/10.1016/j.geoderma.2014.07.005

47. Pérez- Izquierdo L, Saint- André L, Santenoise P, et al (2018) Tree genotype and seasonal effects on soil properties and biogeochemical functioning in Mediterranean pine forests. Eur J Soil Sci 69:1087-1097. https://doi.org/10.1111/ejss.12712

48. Fierer N, Bradford MA, Jackson RB (2007) Toward an ecological classification of soil bacteria. Ecology 88:1354-1364

49. Lauber CL, Hamady M, Knight R, Fierer N (2009) Pyrosequencing-based assessment of soil $\mathrm{pH}$ as a predictor of soil bacterial community structure at the continental scale. Appl Environ Microbiol 75:5111-5120

50. Rutgers M, Wouterse M, Drost SM, et al (2016) Monitoring soil bacteria with communitylevel physiological profiles using Biolog ${ }^{\mathrm{TM}}$ ECO-plates in the Netherlands and Europe. Appl Soil Ecol 97:23-35. https://doi.org/10.1016/j.apsoil.2015.06.007

51. Zechmeister-Boltenstern S, Keiblinger KM, Mooshammer M, et al (2015) The application of ecological stoichiometry to plant-microbial-soil organic matter transformations. Ecol Monogr 85:133-155. https://doi.org/10.1890/14-0777.1

52. Parton W, Silver WL, Burke IC, et al (2007) Global-Scale Similarities in Nitrogen Release Patterns During Long-Term Decomposition. Science 315:361-364. https://doi.org/10.1126/science.1134853

53. Brunel C, Gros R, Ziarelli F, Da Silva AMF (2017) Additive or non-additive effect of mixing oak in pine stands on soil properties depends on the tree species in Mediterranean forests. Sci Total Environ 590:676-685 
609

610

611

612

613

614

615

616

617

618

619

620

621

622

623

624

625

626

627

628

629

630

631

632

633

634

635

636

637

638

639

640

641

642

54. Pearson RG, Dawson TP (2003) Predicting the impacts of climate change on the distribution of species: are bioclimate envelope models useful? Glob Ecol Biogeogr 12:361-371. https://doi.org/10.1046/j.1466-822X.2003.00042.x

55. Pons A, Quézel P (1998) À propos de la mise en place du climat méditerranéen. Comptes Rendus Académie Sci - Ser IIA - Earth Planet Sci 327:755-760. http://dx.doi.org/10.1016/S1251-8050(99)80047-0

56. Sardans J, Peñuelas J (2013) Plant-soil interactions in Mediterranean forest and shrublands: impacts of climatic change. Plant Soil 365:1-33. https://doi.org/10.1007/s11104-013-15916

57. Bhunia RK, Showman LJ, Jose A, Nikolau BJ (2018) Combined use of cutinase and highresolution mass-spectrometry to query the molecular architecture of cutin. Plant Methods 14:117. https://doi.org/10.1186/s13007-018-0384-6

58. Lal R (2018) Digging deeper: A holistic perspective of factors affecting soil organic carbon sequestration in agroecosystems. Glob Change Biol 24:3285-3301. https://doi.org/10.1111/gcb.14054

59. Rowley MC, Grand S, Verrecchia ÉP (2018) Calcium-mediated stabilisation of soil organic carbon. Biogeochemistry 137:27-49. https://doi.org/10.1007/s10533-017-0410-1

60. Yuste JC, Fernandez-Gonzalez AJ, Fernandez-Lopez M, et al (2014) Strong functional stability of soil microbial communities under semiarid Mediterranean conditions and subjected to long-term shifts in baseline precipitation. Soil Biol Biochem 69:223-233

61. Paul EA (2014) Soil microbiology, ecology and biochemistry. Academic press

62. Tardy V, Mathieu O, Lévêque J, et al (2014) Stability of soil microbial structure and activity depends on microbial diversity. Environ Microbiol Rep 6:173-183

63. Chomel M, Guittonny-Larchevêque M, Fernandez C, et al (2016) Plant secondary metabolites: a key driver of litter decomposition and soil nutrient cycling. J Ecol 104:15271541

64. Mutabaruka R, Hairiah K, Cadisch G (2007) Microbial degradation of hydrolysable and condensed tannin polyphenol-protein complexes in soils from different land-use histories. Soil Biol Biochem 39:1479-1492

65. Rovira P, Vallejo VR (2002) Labile and recalcitrant pools of carbon and nitrogen in organic matter decomposing at different depths in soil: an acid hydrolysis approach. Geoderma 107:109-141. http://dx.doi.org/10.1016/S0016-7061(01)00143-4

66. Pook EW, others (1966) The influence of aspect on the composition and structure of dry sclerophyll forest on Black Mountain, Canberra. ACT. Aust J Bot 14:223-242 
643

644

645

646

647

648

649

650

651

652

653

654

655

656

657

658

659

660

661

662

663

664

665

666

667
67. Cantlon JE (1953) Vegetation and microclimates on north and south slopes of Cushetunk Mountain, New Jersey. Ecol Monogr 241-270

68. Martínez-Murillo JF, Gabarrón-Galeote MA, Ruiz-Sinoga JD (2013) Soil water repellency in Mediterranean rangelands under contrasted climatic, slope and patch conditions in southern Spain. Catena 110:196-206

69. Nadal-Romero E, Petrlic K, Verachtert E, et al (2014) Effects of slope angle and aspect on plant cover and species richness in a humid Mediterranean badland. Earth Surf Process Landf 39:1705-1716

70. Maaaren IE, Karki S, Prajapati C, et al (2015) Facing north or south: Does slope aspect impact forest stand characteristics and soil properties in a semiarid trans-Himalayan valley? J Arid Environ 121:112-123

71. Allard V, Ourcival JM, Rambal S, et al (2008) Seasonal and annual variation of carbon exchange in an evergreen Mediterranean forest in southern France. Glob Change Biol 14:714-725. https://doi.org/10.1111/j.1365-2486.2008.01539.x

72. Muñoz- Rojas M, Jordán A, Zavala LM, et al (2015) Impact of Land Use and Land Cover Changes on Organic Carbon Stocks in Mediterranean Soils (1956-2007). Land Degrad Dev 26:168-179. https://doi.org/10.1002/ldr.2194

73. Insam H, Haselwandter K (1989) Metabolic quotient of the soil microflora in relation to plant succession. Oecologia 79:174-178. https://doi.org/10.1007/BF00388474

74. Vicente Serrano SM, López-Moreno JI, Beguería S, et al (2014) Evidence of increasing drought severity caused by temperature rise in southern Europe, Environ. Res Lett, https://doi.org/10.1088/1748-9326/9/4/044001

75. Diamond S, Andeer PF, Li Z, et al (2019) Mediterranean grassland soil C-N compound turnover is dependent on rainfall and depth, and is mediated by genomically divergent microorganisms. Nat Microbiol 4:1356-1367. https://doi.org/10.1038/s41564-019-0449-y 


\section{Figures}

Fig. 1 The overview of experimental design; (a) the schematic representation of the study design. The variables assessed and matrix used to describe geoclimate, vegetation cover, soil characteristics, carbon source utilisation and catabolic potential are fully detailed in the supplementary methods (Appendix 1, Table S1) ; (b) Sampling sites map. The colors of the symbols $(n=60)$ refer to the different forest stands: red and blue tones correspond to meso- and supra-Mediterranean bioclimates, respectively; filled and open symbols correspond to north- and south-exposed plots, respectively.

a

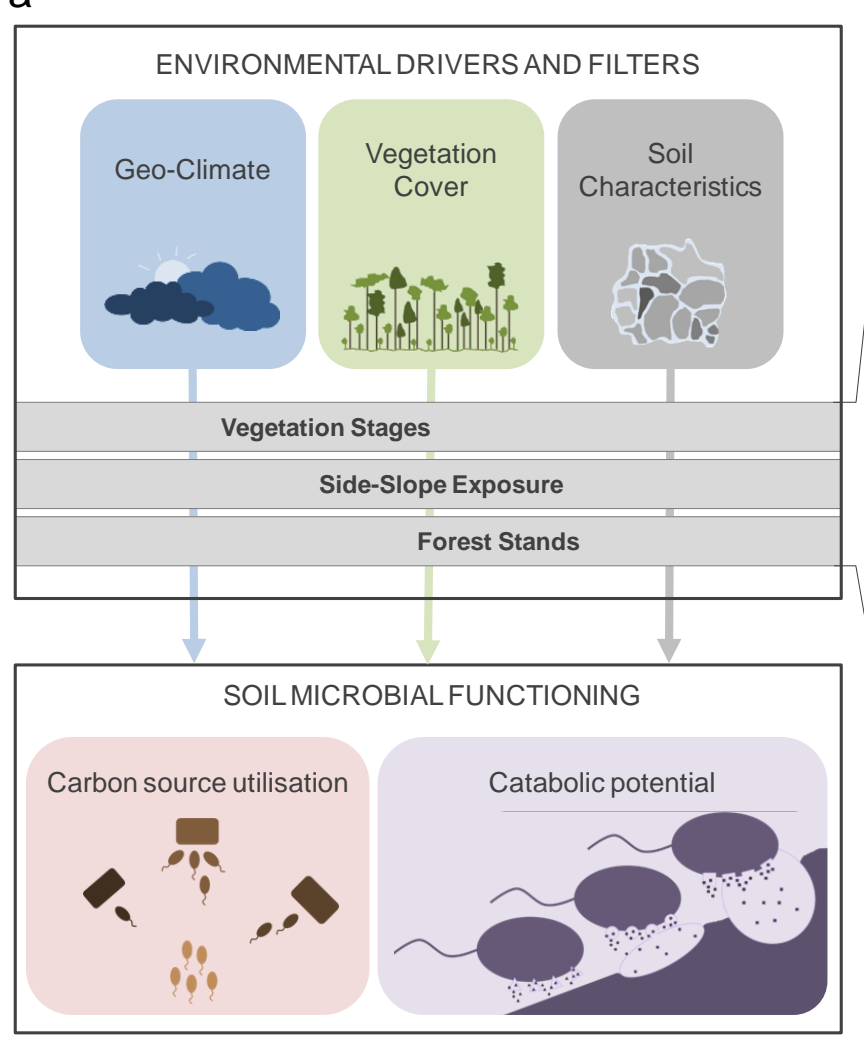

b

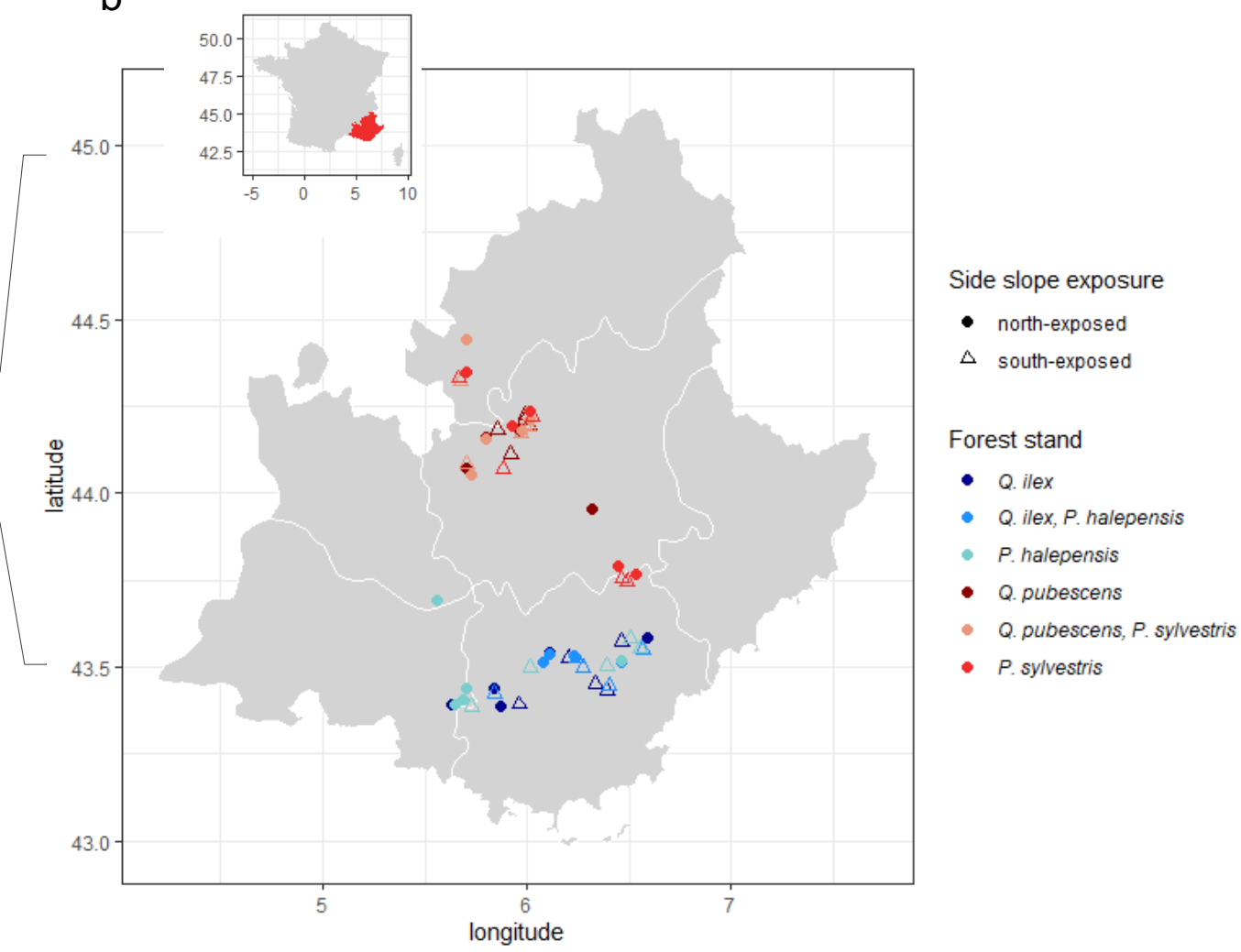


675 Fig. 2 | Nonmetric multi-dimensional scaling (NMDS) of (a) geoclimate, (b) soil, (c) vegetation, (d) carbon source 676 utilisation, and (e) microbial catabolic potential patterns based on Euclidian (a, b, d, e) and Manhattan (c) 677 dissimilarity distances. The colors of the symbols refer to the different forest stands: red and blue tones correspond 678 to meso- and supra-Mediterranean bioclimates, respectively; filled and open symbols correspond to north- and 679 south-exposed plots, respectively. PERMANOVA results of main factors (B for bioclimate, FS for forest stand 680 and SE for slope exposure) are provided above each panel. Interaction effects (all not significant) are provided in 681 Appendix 2, Table S1. 

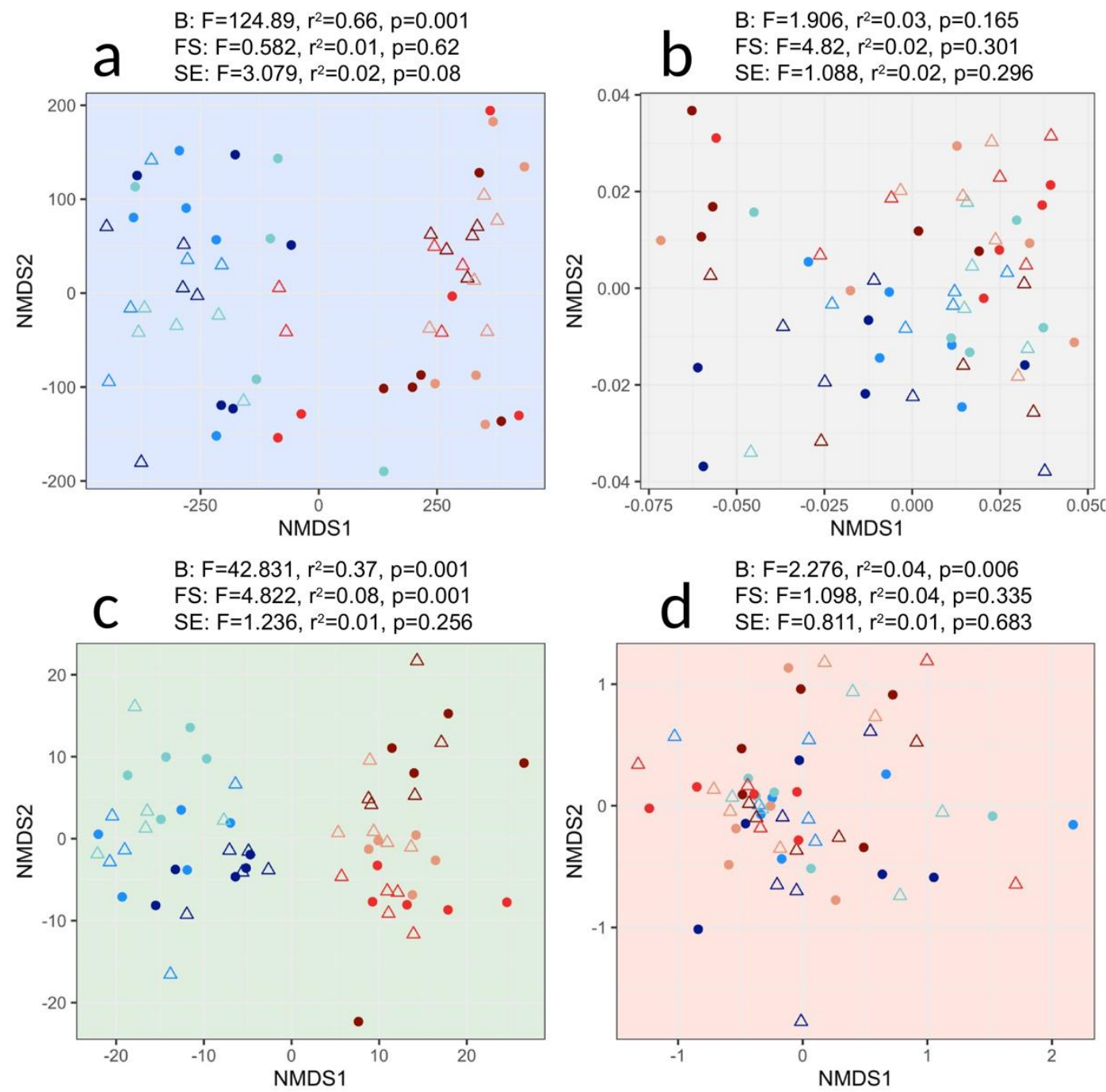

682

$B: F=4.149, r^{2}=0.06, p=0.005$

FS: $F=2.502, r^{2}=0.08, p=0.012$

SE: $F=1.610, r^{2}=0.03, p=0.122$

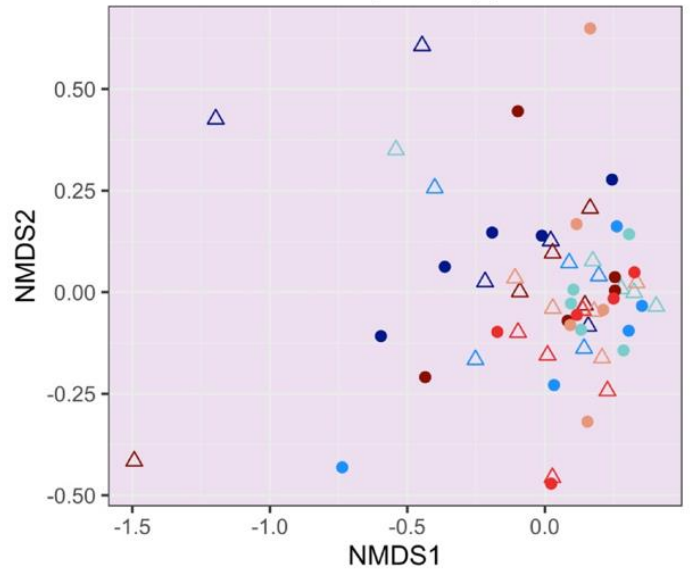

Side slope exposure

- north-exposed

$\Delta$ south-exposed

Forest stand

- Q. ilex

- Q. ilex, P. halepensis

- P. halepensis

- Q. pubescens

- Q. pubescens, P. sylvestris

- P. sylvestris 
Fig. 3 | Shaping of soil biological and chemical characteristics across the considered factorial scales (B for bioclimate, FS for forest stand and SE for slope exposure). Panel a, b, c, d and e respectively stand for the total $\mathrm{N}$, the microbial tyrosinase activities, the $\mathrm{C} / \mathrm{N}$ ratio, the aromaticity ratio and $\mathrm{pH}$ as affected by forest stands (Q/P stands for mixed Quercus/Pinus stands). Panel $\mathrm{f}$ stands for the microbial the slope exposure effect on cellulase activity. Panels $g$ to 1 respectively stand for the water holding capacity, the soil organic carbon, the HR1 ratio, the Carboxyl C fraction, the microbial metabolic quotient and the microbial biomass per unit of organic C respectively, as affected by the meso- or supra- mediterranmean bioclimates. Only significant effects, i.e., $\mathrm{p} \leq 0.05$ after Benjamini and Hochberg (1995) post-hoc correction, are shown.
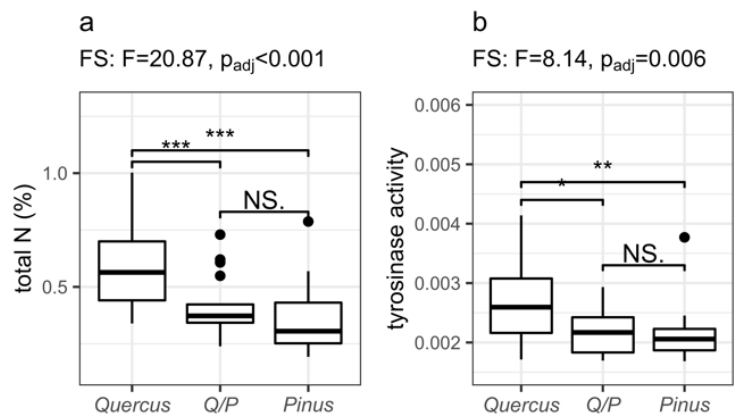

$C$

$\mathrm{d}$

FS: $F=8.06, p_{\text {adj }}=0.006$

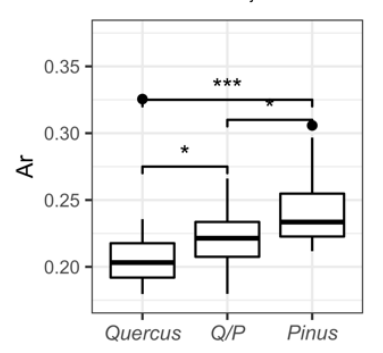

e

FS: $F=6.333, p_{\text {adj }}=0.020$
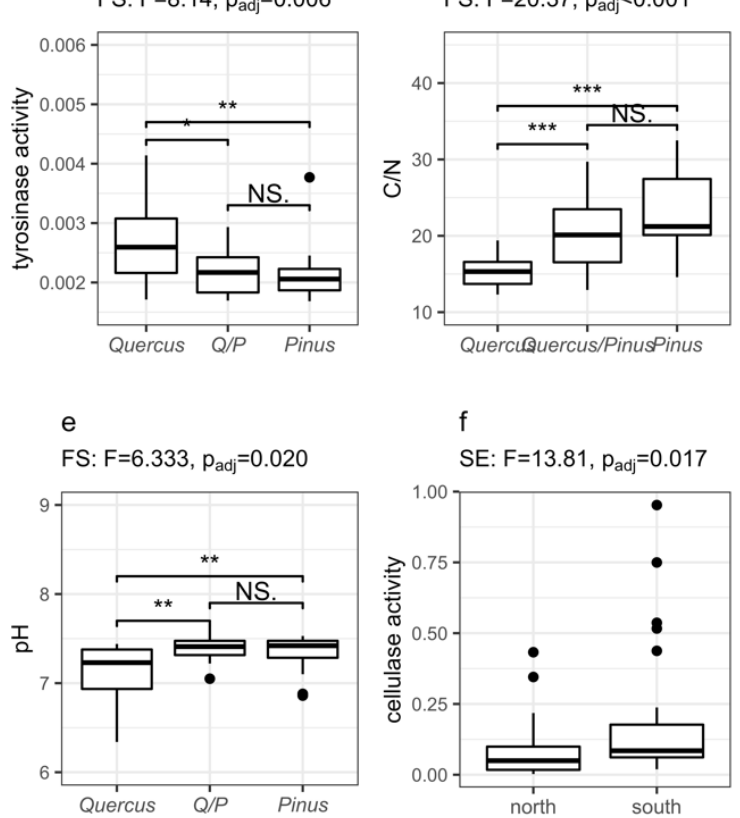

$$
\text { g }
$$

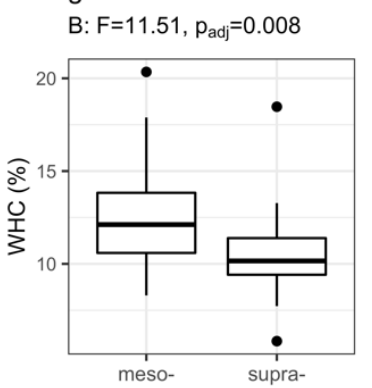

h

$B: F=27.76, p_{\text {adj }}<0.001$

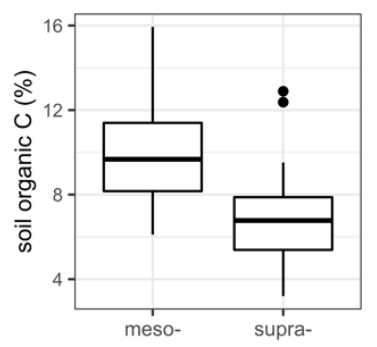

i

$B: F=7.58, p_{a d j}=0.039$

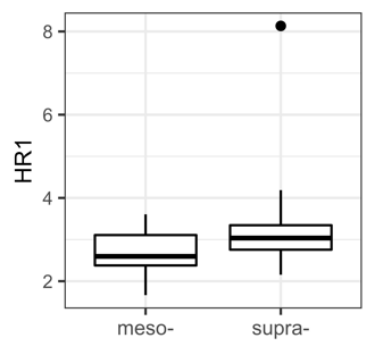

j

$B: F=16.10, p_{a d j}=0.001$

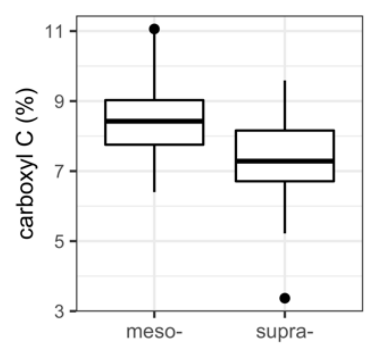

$$
\mathrm{k}
$$

B: $F=20.50, p_{a d j}<0.001$
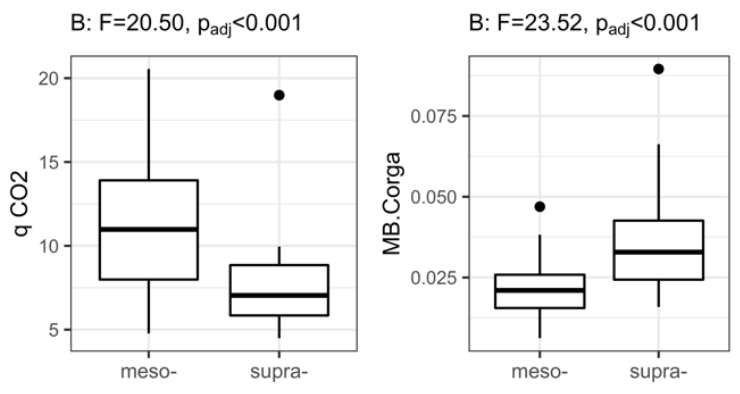
Fig. 4 | Variation partitioning of soil microbial carbon source utilisation (a, b and c) and catabolic potential (d, e and f) into soil, vegetation and geoclimate components at different spatial scales (a and $\mathrm{d}$ at the regional-scale $(n=60)$; $\mathrm{b}$ and e at the sub-regional meso-Mediterranean scale $(n=30)$; and $\mathrm{c}$ and $\mathrm{f}$ at the sub-regional supra-Mediterranean scale $(n=30)$ ). Each Venn diagram represents a given biological variation $\left(\mathrm{r}^{2}\right)$ partitioned into the relative effects of each components or combination of components. Pure and shared effects of the different fractions were analyzed by constrained and un-constrained db-rda tests respectively, and are reported in the Table S3. Significant component are underlined when implying a pure effect and are enclosed by a bold line when implying a whole component.
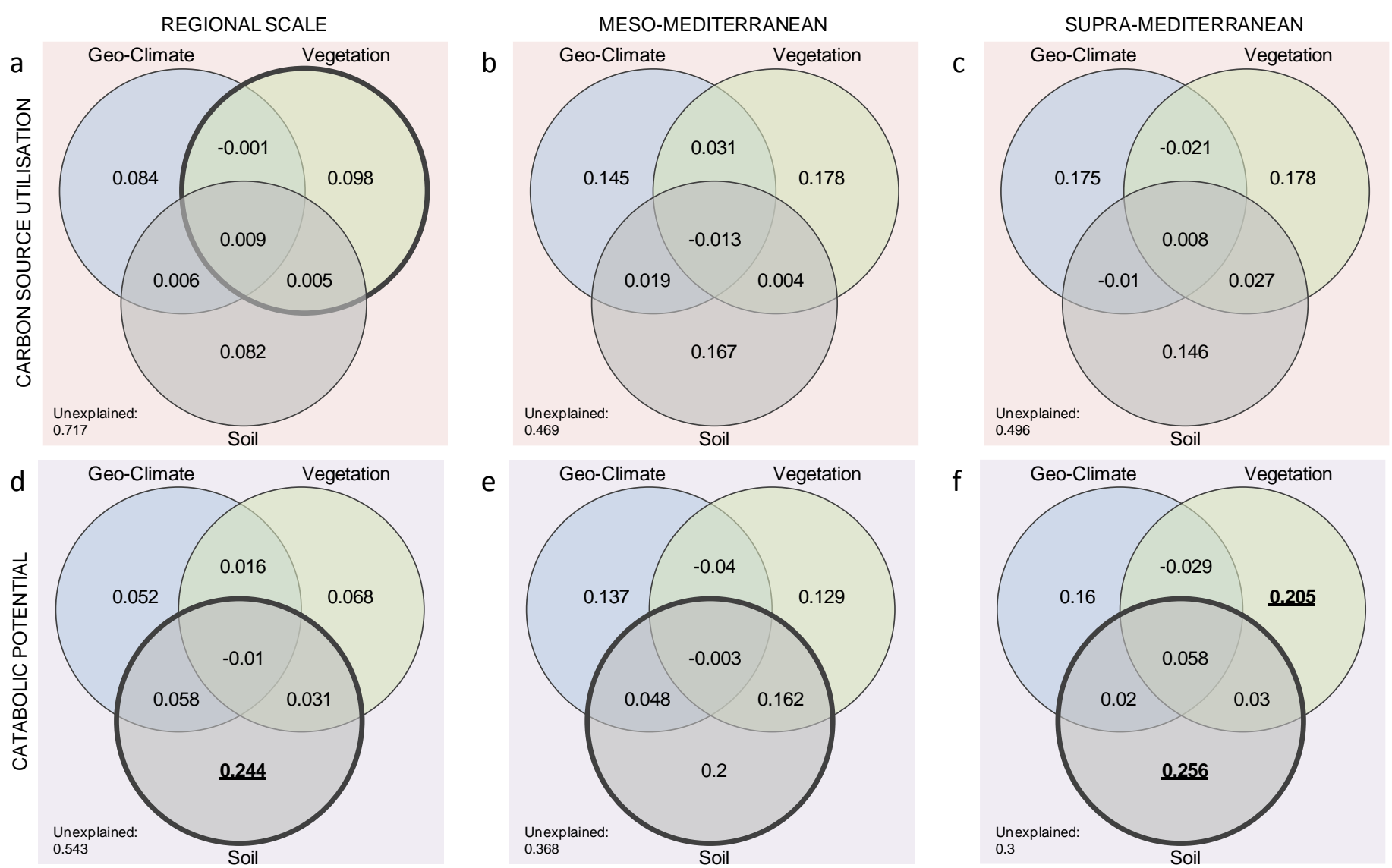
Fig. 5 | Heat map of Spearman correlation coefficient (rho) between microbial and environmental variables. The color ramp refers to the Spearman correlation coefficient, blue tones stand for positive relations and red tones for negative relations, and the point size refers to the correlation strength (abs(rho)). Top annotations refer to environmental variables and left annotations to microbial variables $\left(\mathrm{D}_{\text {sea }}\right.$ : distance to the sea; $\mathrm{P}$ seasonality: precipitation seasonality; TAR: temperature annual range; $\mathrm{T}$ seasonality : temperature seasonality; MTWaQ: maximum temperature of the warmest quarter; minTCM: minimum temperature of the coldest month; MTDQ: mean temperature of the driest quarter ; MTCQ: mean temperature of the coldest quarter; annual P: annual precipitation; PWaQ: precipitation of the warmest quarter; annual MT: annual mean temperature; max TWaM: maximum temperature of the warmest month; MDR: mean diurnal range; PDQ: precipitation of the driest quarter; PDM: precipitation of the driest month; WHC: water holding capacity; HR1: humification ratio 1; A/G: angiosperm to gymnosperm ratio; BR: basal respiration; MB: microbial biomass; $\mathrm{qCO}_{2}$ : metabolic quotient; MB.Corga: microbial biomas per unit of organic carbon). Only variables that show significant correlations are shown, i.e., $\mathrm{p} \leq 0.05$ after Benjamini and Hochberg (1995) post-hoc correction.

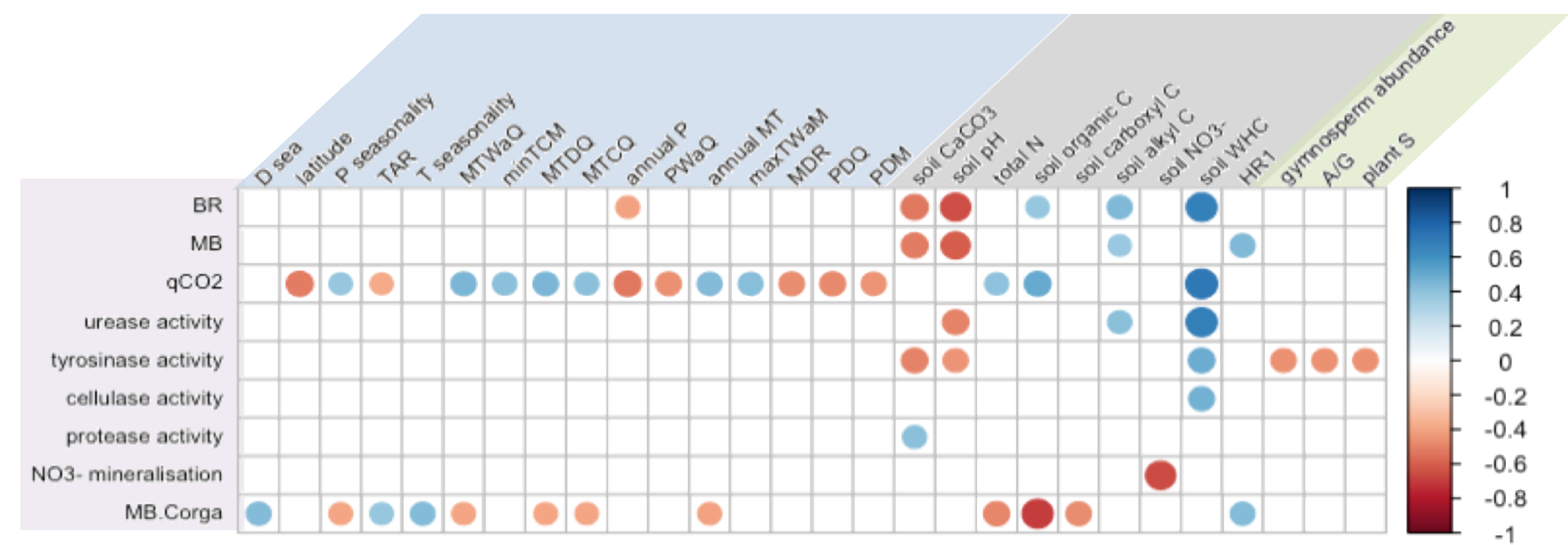


Click here to access/download Supplementary Material Appendix_1_Sup_Methods_rev1.doc 
Click here to access/download Supplementary Material Appendix_2_Sup_Results_rev1.doc 